\title{
STUDI KOMPARASI TINGKAT ASERTIFITAS PADA MAHASISWA PG-PAUD DI UNIVERSITAS MUHAMMADIYAH PONTIANAK Sri Nugroho Jati ${ }^{1}$ Diana $^{2}$
}

Fakultas Keguruan dan Ilmu Pendidikan, Universitas Muhammadiyah Pontianak noenoenk76@yahoo.com

\begin{abstract}
Abstrask : Penelitian ini adalah penelitian dekriptif komparatif untuk menggambarkan perbandingan tingkat asertifitas mahasiswa PG-PAUD ditinjau dari hasil The Rathus Assertiveness Schedule (RAS) dan Assertiveness Rating Scale (ARS). Subjek penelitian ini adalah mahasiswa PGPAUD angkatan tahun 2011 dan 2012 yang keseluruhannya berjumlah 70 mahasiswa. Alat ukur yang dipakai dalam penelitian ini adalah The Rathus Assertiveness Schedule (RAS) dan Assertiveness Rating Scale (ARS) yang dimodifikasi. Dalam skala asertivitas mengukur tingkat asertifitas individu dengan menetapkan tiga kategori penilaian yaitu sepanjang waktu (skor 3), kadangkadang (skor 2) dan jarang (skor 1). Skala asertifitas ini di Analisis data akan dilakukan secara deskriptif yaitu menguraikan skor data hasil skala asertifitas pada 66 mahasiswa secara kuantitatf dan secara statistic dengan menggunakan uji t untuk melihat perbandingan variabel.

Hasil penelitian Berdasarkan analisis data yang dialakukan dengan menggunakan teknik korelasi Pearson (2 taled), menunjukkan tidak ada hubungan yang sangat signifikan perilaku asertif pada mahasiswa PGPAUD pada angkatan 2011 dan 2012 yaitu diketahui dari nilai $\mathrm{r}$ yang diperoleh sebesar $-0,87$ dengan signifikansi 0,629 >0,05 ( $>00,05)$. Dari hasil tersebut, maka dapat dikatakan bahwa secara keseluruhan dari perhitungan uji statistik yang dilakukan disimpulkan bahwa tidak ada perbedaan tingkat asertifitas pada mahasiswa PGPAUD angkatan tahun 2011 dan 2012, yaitu t hitung $(1,816)<\mathrm{t}$ tabel $(2,04)$, sehingga Ha ditolak dan $\mathrm{H}_{0}$ diterima.
\end{abstract}

Kata Kunci : Studi Komparasi, Assertiveness, Mahasiswa

Abstract : This study is a comparative descriptive study to illustrate the comparative level of student asertifitas PG-PAUD in terms of the results of the Rathus Assertiveness Schedule (RAS) and Assertiveness Rating Scale (ARS). The subjects were students PGPAUD force in 2011 and 2012 the total amounted to 70 students. Measuring instrument used in this study is the Rathus

${ }^{1}$ Sri Nugroho Jati : Dosen PAUD FKIP UMP

${ }^{2}$ Dian : Dosen PAUD FKIP UMP 
Assertiveness Schedule (RAS) and Assertiveness Rating Scale (ARS) are modified. In assertiveness scale measuring the level of individual asertifitas to establish three categories of assessment that is all the time (score 3), occasionally (score 2) and rare (score 1). This asertifitas scale in the data analysis will be carried out descriptive outlines asertifitas scale score outcome data on 66 students in kuantitatf and statistically by using t tests to compare variables. Based on the research results of data analysis done by using the Pearson correlation technique ( 2 taled), showed no significant relationship assertive behavior in students PGPAUD force in 2011 and 2012 that is known of the value of $\quad r$ obtained at -0.87 with significance $0,629>0.05$ ( $p>0.05)$. From these results, it can be said that overall from the calculation of statistical tests performed concluded that there was no difference in the level of the student asertifitas PGPAUD of 2011 and 2012 years, $t$ count $(1.816)<t$ table (2.04), so that $\mathrm{Ha}$ is rejected and $\mathrm{H}_{0}$ is accepted.

\section{Keywords: Comparative Studies, Assertiveness, Student}

\section{Latar Belakang Masalah}

Perilaku asertif adalah perilaku yang merupakan ekspresi/pernyataan dari minat, kebutuhan, pendapat, pikiran, dan perasaan yang dilakukan secara bijaksana, adil dan efektif, shingga hak-hak bisa dipertahankan dengan tetap memperhatikan penghargaan atas kesetaraan dan hak orang lain. Dengan kata lain perilaku asertif dikonotasikan dengan perilaku tegas. Untuk bisa bersikap asertif dibutuhkan sikap yang dapat mengkomunikasikan apa yang diinginkan, dirasakan, dan dipikirkan kepada orang lain, sehingga bisa secara terbuka mengekspresikan diri tanpa menyakiti perasaan orang lain. Sikap tersebut merupakan criteria yang harus dipersiapkan oleh para calon intelekual muda yaitu mahasiswa. Sebagai "agent of change", mahasiswa seharusnya memiliki sikap-sikap asertif. Mahasiswa yang memiliki perilaku asertivitas cenderung dapat bekerja sama dan dapat berkembang untuk mencapai tujuan yang lebih baik, tingkat sensitivitas yang dimiliki cukup tinggi sehingga dapat membaca situasi yang terjadi di sekelilingnya dan memudahkan untuk beradaptasi. Dalam hal melakukan kegiatannya, mahasiswa yang asertif akan bisa melakukan aktivitasnya secara terarah, strategis, dan terkendali.

Kurangnya perilaku asertif ini juga ditunjukkan oleh mahasiswa di Universitas Mahasiswa Pontianak. Berdasarkan pengamatan yang telah dilakukan, mahasiswa cenderung kurang asertif ketika berada pada situasi proses pembelajaran di kelas. Umumnya mahasiswa pada angkatan pertama yang mengalami perilaku non asertif, karena masih dalam masa transisi dari bangku SMU ke jenjang perguruan tinggi sehingga memerlukan proses untuk bisa lebih beradaptasi dengan lingkungan dan situasi kampus. Akan tetapi akan 
menjadi satu permasalahan apabila pada tingkat semester berikutnya belum mengalami perubahan dan perkembangan.

\section{Perilaku Asertif}

Kata asertif berasal dan bahasa Inggris yaitu "to assert" yang berarti positif yaitu menyatakan sesuatu dengan terus-terang atau tegas serta bersikap positif (Fensterheim dan Baer, 1995). Menurut Mallot, dkk (Prabana, 1997), "to asser" artinya sebagai cara menyatakan sesuatu dengan sopan mengenai hal-hal yang menyenangkan maupun yang dirasa mengganggu atau kurang berkenan Sedangkan menurut Ramus dan Nevid (Prabana, 1997) "to assert" berarti meminta seseorang untuk melakukan sesuatu dengan cara yang akan menambah penghargaan atau mengurangi aversi (rasa enggan). Menurut Mulvani (dalam Retnaningsih, 1992) perilaku asertif adalah perilaku pribadi menyangkut emosi yang tepat, jujur, relatif terus terang, tanpa perasaan cemas pada orang lain.

Perilaku asertif seseorang pada hakekatnya mencakup tiga klasifikasi umum perilaku, yaitu tepat dalam cara menolak permintaan orang lain, ekspresi yang tepat dari pikiran-pikiran dan perasaan-perasaan serta ekspresi yang tepat dari keinginan-keinginan yang dimiliki (Wood dan Mallinekrodt dalam Prabana, 1997). Kelley (Prabana, 1997) mengatakan bahwa asertif adalah sikap seseorang dalam mengekspresikan dirinya dengan landasan hak pribadinya sendiri tanpa menyakiti atau menyinggung hak pribadi orang lain Perilaku asertif merupakan ekspresi yang tepat dari beberapa emosi selain kecemasan kepada orang lain (Wolpe dalam Prabana, 1997).

Bloom, dkk (1991) mengemukakan bahwa perilaku asertif berada di tengah-tengah antara perilaku agresif di satu sisi dan perilaku pasif di sisi lain. Maksud perilaku asertif adalah perilaku untuk berkomunikasi secara langsung dan terbuka, sedangkan perilaku agresif adalah untuk rnendominasi, untuk mendapatkan apa yang diinginkannya dengan mengorbankan orang lain. Sedangkan perilaku pasif merupakan perilaku yang tidak menyatakan perasaan, gagasan, dan kebutuhannya dengan tepat serta mengabaikan hakhaknya sendiri. Perilaku pasif ini biasanya bersifat emosional, tidak jujur dan tidak langsung, terhambat dan menolak diri sendiri. Individu yang pasif akan membiarkan orang lain menentukan apa yang harus dilakukannya dengan sering berakhir dengan perasaan cemas, kecewa terhadap diri sendiri, bahkan kemungkinan akan berakhir dengan kemarahan dan perasaan tersinggung.

Dan uraian pendapat para ahli tersebut, maka dapat ditarik kesimpulan bahwa perilaku asertif adalah sikap atau perilaku ailar pribadi yang menyangkut ekspresi keinginan-keinginan, kebutuhan-kebutuhan, serta perasaan-perasaan secara tepat. jujur, relatif terbuka, dan langsung mengarah 
ke tujuan. Adapun ciri-ciri dari perilaku asertif adalah penuh percaya diri dan teguh pada pendiriannya serta tanpa adanya perasaan cemas terhadap orang lain, tanpa mengesampingkan, menyakiti ataupun mengecilkan arti orang lain, dan tidak melanggar hak-hak orang lain baik melalui gerakan-gerakan tubuh seperti mimik, postur tubuh, gerak tubuh, nada dan tekanan suara, serta tindakan tanpa perasaan cemas dan mencemaskan orang lain. Orang-orang yang asertif tidak merasa malu dalam suatu pertemuan, dapat menjalin hubungan yang baik dengan orang yang belum dikenalnva dan juga menunjukkan perasaan yang positif terhadap sesuatu maupun pada orang lain, dengan demikian perilaku asertif selain bersifat langsung juga harus memperhatikan dan menghormati keadaan orang lain, serta memberikan rasa percaya diri pada seseorang seperti pujian. serta dapat mengkomunikasikan sesuatu pada orang Iain.

\section{Aspek-aspek aserifitas}

Menurut Radius (Reputrawati, 1996) aspek-aspek asertivitas adalah:

a. Menolak hal-hal yang tidak sesuai dengan dirinya seperti permintaan dan gagasan

b. Mampu mengekspresikan perasaan positif dengan baik

c. Jujur, terbuka, dan memberikan penghargaan pada orang lain tanpa menyakiti atau mengesampingkan ataupun mengecilkan arti orang lain

d. Percaya din (Self confidence)

e. Mampu berkomunikasi atau berbicara

f. Mengajukan permintaan dan bantuan pada orang lain tanpa rasa enggan.

\section{Faktor-faktor yang mempengaruhi asertifitas}

1. Jenis Kelamin

Penelitian Bee (Retnaningsih, 1992) menambahkan laki-iaki cenderung lebih mandiri, tidak mudah terpengaruh, dan lebih tenang, perempuan lebih mudah terpengaruh dan lebih bersifat mendidik.. Jenis kelamin yang dianggap mempunyai pengaruh terhadap perilaku asertif biasanya berhubungan dengan pola asuh, budaya, serta stereotip yang ada.

2. Harga Diri

Bloom, dkk (Retnaningsih, 1992) mengemukakan bahwa antara harga diri dengan asertivitas mempunyai hubungan yang sangat erat dan saling berkaitan. Individu yang mempunyai harga diri tinggi akan mampu berperilaku asertif dan kemampuannya dalam berperilaku asertif akan meningkatkan pula harga dirinya.

3. Pola asuh orang tua dan lingkungan 
Menurut Rathus dan Domikus (Prabana, 1997) tingkah laku asertif beikembang secara bertahap sebagai hasil interaksi antara anak dan orang tua serta orang-orang dewasa lain disekitarnya karena semenjak anakanak, peran pendidikan perempuan dan laki-laki telah dibedakan oleh masyarakat artinya sejak kecil anak laki-laki dibiasakan tegas dan kompetitif.

4. Kebudayaan

Sue, dkk (Reputrawati, 1996) mengatakan bahwa mahasiswa Amerika keturunan Asia pada umumnya lebih introvert., tidak asertif dan pasif jika dibandingkan dengan mahasiswa Amerika keturunan Eropa.

5. Tingkat Pendidikan

Caplow (Yogaryjantono, 1991) mengatakan bahwa semakin tinggi tingkat pendidikan seseorang akan semakin ada kecenderungan untuk sukses dalam bekerja.

6. Jenis pekerjaan dan lama kerja

Koentjoro (1987) yang menyatakan bahwa beberapa hal yang diduga mempengaruhi self asertiveness adalah pekerjaan yang banyak menuntut hubungan interpersonal.

7. Kondisi sosial ekonomi dan inteligensi

Ditunjukkan oleh hasil peneiitian Sehartz dan Gottman (Retnaningsih, 1992) menunjukkan bahwa individu yang memiliki status sosial ekonomi dan intelegensi yang tinggi pada umumnya tinggi pula nilai asertivitasnya.

\section{Assertiveness Rating Scale (ARS) dan The Rathus Assertivenness Schedule $(\boldsymbol{R A S})$}

Assertiveness Rating Scale adalah salah satu skala penilaian yang berisi daftar pernyataan yang mengukur tingkat asertif seseorang. Terdiri dari 15 item pernyataan tentang karakter/sifat/kepribadian yang meliputi pilihan jawaban yaitu : sepanjang waktu, kadang-kadang, jarang-jarang. Item-item dalam Assertiveness Rating Scale (ARS) ini dikembangkan lagi dalam The Rathus Assertiveness Scale (RAS).

The Rathus Assertiveness Schedule (RAS). RAS adalah salah satu alat penilaian yang sering digunakan oleh peneliti di Amerika Serikat untuk mengukur asertifitas diri dan telah diterjemahkan ke dalam pelbagai bahasa bagi kegunaan di negara-negara lain (Corcoran \& Fischer 2000; Elliott \& Gramling 1990; Meier \& Hope 1998; Poyrazli 2000; Poyrazli et al. 2002; Quillin, Besing \& Dinning 1977). Menurut Rathus, alat penilaian ini mengandung 30 item yang meliputi item positif dan negatif. Responden diminta memberi respon sejauh manakah setiap item yang diberikan itu dapat menggambarkan diri mereka. 
Beberapa item telah diubah disesuaikan agar pernyataan yang diberikan dalam soalan tersebut dapat disesuaikan dengan budaya setempat. Skor yang tinggi menggambarkan seseorang itu adalah seorang yang asertif.

\section{Mahasiswa}

Mahasiswa Pengertian Definisi Mahasiswa dalam peraturan pemerintah RI No.30 tahun 1990 adalah peserta didik yang terdaftar dan belajar di perguruan tinggi tertentu. Selanjutnya menurut Sarwono (1998) mahasiswa adalah setiap orang yang secara resmi terdaftar untuk mengikuti pelajaran di perguruan tinggi dengan batas usia sekitar 18-30 tahun.

Mahasiswa merupakan suatu kelompok dalam masyarakat yang memperoleh statusnya karena ikatan dengan perguruan tinggi. Mahasiswa juga merupakan calon intelektual atau cendekiawan muda dalam suatu lapisan masyarakat yang sering kali syarat dengan berbagai predikat.

Pengertian Mahasiswa menurut Knopfemacher (dalam Sarwono, 1998) adalah merupakan insane-insan calon sarjana yang dalam keterlibatannya dengan perguruan tinggi (yang makin menyatu dengan masyarakat), dididik dan di harapkan menjadi calon-clon intelektual.

\section{METODE PENELITIAN Model Penelitian}

Assertiveness Rating scale dan The Rathus Assertiveness Schedule merupakan suatu skala pengukuran diri yang dalam penelitian ini akan dihitung secara kuantitatif, hasil dari skor masing-masing item akan dijumlahkan, kemudian di lihat precentilnya. Setelah itu hasilnya di ukur untuk menentukan tingkat asertifitas secara keseluruhan. Pada Assertiveness Rating scale, pernyataan dari perilaku asertifitas dinyatakan dalam pilihan jawaban : sebagian besar waktu, kadang-kadang dan sangat tidak sering. Sedangkan pada The Rathus Assertiveness Schedule jawaban dikategorikan pada 6 pilihan jawaban : Sangat seperti saya, agak seperti saya, sedikit seperti saya, sedikit tidak seperti saya, agak tidak seperti saya, sangat tidak seperti saya. Sebagian item pada ARS terdapat juga dalam RAS, sehingga skala asertif nantinya merupakan penggabungan ARS dan RAS. Skor yang tinggi dalam skala ini menggambarkan seseorang itu adalah seorang yang asertif.

Secara kualitatif, posisi asertifitas dari setiap pernyataan pada skala pengukuran menjadi gambaran profil tingkat asertifitas masing-masing. Dengan demikian, meskipun secara kuantitatif skor tingkat asertfitasnya bisa sama, akan tetapi secara kualitatif arah stimulasi dari setiap mahasiswa bisa berbeda tergantung profil dari hasil RAS dan ARS nya. Dari hasil 
keseluruhan skoring ARS dan RAS masing-masing mahasiswa akan dibedakan lagi berdasar angkatan tahun 2011 dan 2012.

Penelitian ini dilaksanakan di Universitas Muhammadiyah Pontianak, Jl. A.Yani No. 111 Pontianak. Waktu penelitian akan dilaksanakan selama enam-delapan bulan.

\section{Rancangan Penelitian}

Penelitian ini adalah penelitian komparatif yaitu membandingkan tingkat asertivitas pada mahasiswa PG-PAUD angkatan tahun 2011 dan 2012. Metoda penentuan sampel yang digunakan adalah metode purposive sampling. Purposive Sampling digunakan apabila obyek yang akan diteliti atau sumber data sangat luas (Sugiyono, 2010) Purposive sampling adalah metode pengambilan sampel yang dipilih dengan cermat sehingga relevan dengan struktur penelitian, dimana pengambilan sampel dengan mengambil sample orang-orang yang dipilih oleh penulis menurut ciri-ciri spesifik dan karakteristik tertentu. (Djarwanto,1998)

\section{Subyek Penelitian}

Subyek dalam penelitian ini adalah pada mahasiswa program studi PG-PAUD berjumlah 70 orang yang diambil dari mahasiswa angkatan 2011 dan angkatan 2012. Jenis kelamin dalam penelitian ini diabaikan karena hampir 99\% mahasiswa PG-PAUD berjenis kelamin perempuan.

\section{Instrumen Penelitian}

Instrumen yang digunakan dalam penelitian ini adalah adalah skala asertifitas yang diadaptasi dari Assertiveness Rating Scale dan The Rathus Assertiveness Schedule. Instrumen skala sebagai alat ukur adalah sebagai berikut :

\section{Tabel 1}

Blue Print Instrumen

\begin{tabular}{|c|l|l|}
\hline NO & Pernyataan & No item \\
\hline 1 & Favorable & $2,4,6,7,11,13,14,15,17,18,24,25,27,28,30$ \\
\hline 2 & Unfavorable & $1,3,5,8,9,10,12,16,19,20,21,22,23,26,29$ \\
\hline
\end{tabular}

\section{Teknik Pengumpulan Data Penelitian}

Adapun teknik pengumpulan data penelitian ini menggunakan :

- Hasil penilaian dan pengukuran Assertiveness Rating Scale dan The Rathus Assertiveness Schedule.

- Penelusuran Kepustakaan 


\section{Teknik Analisa Data}

Analisis terhadap data akan dilakukan secara kuantitatif deskriptif dan uji statistik menggunakan teknik independent sample t-test.

\section{HASIL DAN PEMBAHASAN}

\section{Pelaksanaan Penelitian}

Pengambilan Data dilaksanakan dengan meyebarkan skala asertifitas pada mahasiswa PG-PAUD. Dari form yang disebar sebanyak 80 eksemplar hanya 66 form yang terisi. Pelaksanaan penelitian di lakukan pada tanggal 1 juli 2014 pada mahasiswa PGPAUD angkatan 2011 dan 2012 kelas A dan B. Tempat pelaksanaan dilakukan di kelas masing-masing dan waktu yang digunakan untuk mengisi form skala asertifitas yaitu selama 1,5 jam. Seperti yang pada awalnya direncanakan, jumlah fom yang akan disebar 80 eksemplar, akan tetapi menjadi berkurang dikarenakan ada subjek yang tidak masuk kuliah dan tidak mengembalikan sehingga berkurang jumlahnya.

\section{Hasil Penelitian dan Pembahasan}

Penelitian ini bertujuan untuk membandingkan tingkat asertifitas mahasiswa PGPAUD yang dibedakan berdasar tahun angkatan studi dari hasil skala asertifitas. Berdasarkan analisis data yang dialakukan dengan menggunakan teknik korelasi Pearson (2 taled), diketahui nilai $\mathrm{r}$ yang diperoleh sebesar -0,87 dengan signifikansi 0,629 > 0,05 ( $p>0,05)$. Dari hasil tersebut, maka dapat dikatakan bahwa tidak ada hubungan yang sangat signifikan perilaku asertif pada mahasiswa PGPAUD pada angkatan 2011 dan 2012. Secara keseluruhan dari perhitungan uji statistik yang dilakukan disimpulkan bahwa tidak ada perbedaan tingkat asertifitas pada mahasiswa PGPAUD tahun angkatan 2011 dan 2012, yaitu t hitung $(1,816)<\mathrm{t}$ tabel $(2,04)$, sehingga $\mathrm{Ha}$ ditolak dan $\mathrm{H}_{0}$ diterima.

Uji statistik dari hasil penelitian adalah ditunjukkan pada tabel berikut :

Tabel 2

Uji Statistik Sampel

Paired Samples Statistics

\begin{tabular}{|l|r|r|r|r|}
\hline & Mean & N & Std. Deviation & \multicolumn{1}{|c|}{ Std. Error Mean } \\
\hline Pair 1 Angkatan 2011 & 63.39 & 33 & 4.776 & .831 \\
\hline
\end{tabular}




\begin{tabular}{|}
\begin{tabular}{|l|r|r|r|r|}
\hline Angkatan 2012 & 60.82 & 33 & 6.197 & 1.079 \\
\hline & Paired Samples Correlations \\
\hline & $\mathrm{N}$ & Correlation & Sig. \\
\hline Pair 1 & Angkatan 2011 \& Angkatan 2012 & 33 & -.087 & .629 \\
\hline
\end{tabular}
\end{tabular}

Paired Samples Test

\begin{tabular}{|c|c|c|c|c|c|c|c|c|c|}
\hline & \multicolumn{5}{|c|}{ Paired Differences } & \multirow[b]{3}{*}{$t$} & \multirow[b]{3}{*}{ df } & \multirow[b]{3}{*}{ Sig. (2-tailed) } \\
\hline & & \multirow[b]{2}{*}{ Mean } & \multirow{2}{*}{\begin{tabular}{|c} 
Std. \\
Deviati \\
on
\end{tabular}} & \multirow{2}{*}{$\begin{array}{c}\text { Std. Error } \\
\text { Mean }\end{array}$} & \multicolumn{2}{|c|}{$\begin{array}{c}95 \% \text { Confidence } \\
\text { Interval of the } \\
\text { Difference } \\
\end{array}$} & & & \\
\hline & & & & & Lower & Upper & & & \\
\hline Pair 1 & $\begin{array}{l}\text { Angkatan } 2011 \\
\text { - Angkatan } \\
2012\end{array}$ & 2.576 & 8.147 & 1.418 & -.313 & 5.465 & $\begin{array}{r}1.81 \\
6\end{array}$ & 32 & .079 \\
\hline
\end{tabular}

Rendahnya tingkat asertifitas mahasiswa PGPAUD dikarenakan kurangnya mahasiswa untuk bisa menyampaikan kebutuhannya atau mengungkapkan maksud mengenai apa yang harus dilakukan dan secara tepat menempatkan atas apa yang harus dilakukan dan dirasakan, serta kurang percaya diri. Situasi lingkungan sekitar turut mempengaruhi subjek dalam tinginya berespon asertif. Seperti yang diungkapkan oleh Rathus dan Nevid (1983) dalam berperilaku asertif seseorang biasanya melihat kondisi dan situasi dalam arti luas. Selain itu kurang percaya diri bisa menyebabkan rendahnya tingkat asertifitas. Mahasiswa PGPAUD secara keseluruhan berjenis kelamin perempuan. Seperti yang diungkapkan Middlebrook (dalam Herni Rosita, 2000), perempuan cenderung dianggap lemah dan harus dilindungi, sedangkan laki-laki dianggap sebaliknya sehingga secara tidak langsung berpengaruh terhadap rasa percaya diri.

\section{KESIMPULAN DAN SARAN}

\section{Kesimpulan}

Dari hasil penelitian mengenai perbandingan asertifitas mahasiswa PGPAUD ditinjau dari hasil ARS dan RAS yang dilakukan pada 66 responden yaitu mahasiswa PGPAUD angkatan 2011 dan 2012, maka disimpulkan sebagai berikut : 
1. Secara keseluruhan hasil yang diperoleh bahwa tidak ada perbedaan yang signifikan tingkat asertifitas mahasiswa PGPAUD angkatan 2011 dan 2012.

2. Hasil analisis statistic tentang tingkat asertifitas mahasiswa diperoleh hasil $\mathrm{t}$ hitung $(1,816)<\mathrm{t}$ tabel $(2,04)$, sehingga $\mathrm{Ha}$ ditolak dan $\mathrm{H}_{0}$ diterima.

3. Secara kualitatif rendahnya tingkat asertifitas mahasiswa PGPAUD dikarenakan kurangnya mahasiswa untuk bisa menyampaikan kebutuhannya atau mengungkapkan maksud mengenai apa yang harus dilakukan dan secara tepat menempatkan atas apa yang harus dilakukan dan dirasakan, serta kurang percaya diri. Situasi lingkungan sekitar turut mempengaruhi subjek dalam tingginya respon asertif

Saran

1. Kemampuan asertifitas mahasiswa lebih ditingkatkan lagi, dengan diberikan stimulasi lingkungan yang mendukung,

2. Memberikan kesempatan untuk mengoptimalkan potensi yang dimiliki dengan meningkat kemampuan komunikasi yang tepat.

\section{DAFTAR PUSTAKA}

Bloom. L. Z., Coburn, K., Pearlman, J. The New Assertive Woman (1975) NY: Dell Publishing Co. Inc

Calhoun, J. F., Acocella, J. R. 1990. Psychology of Adjustment and Human Relationship . New York: McGraw Hill, Inc.

Djarwanto dan Pangestu Subagyo. 2006. Statistik Induktif. Yogyakarta: BPFE-. UGM

Fensterhem, H. \& Baer, J. 1995. Jangan Bilang Ya Bila Anda Akan Menyatakan Tidak (Terjemahan). Jakarta: Gunung Jati

Ismayudha, Y. T., (1995). Pengaruh pelatihan asertif terhadap kecemasan sosial pada remaja. Skripsi . Yogyakarta : Universitas Gajahmada.

Prabana. 1997. Perbedaan Asertivitas Remaja ditinjau dari Status Sosial Ekonomi Orangtua dan Jenis Kelamin. Yogyakarta. Skripsi (tidak diterbitkan). Fakultas Psikologi UGM Yogyakarta.

Nevid, J. S., \& Rathus, S. A. (1978). Multivariate and normative data pertaining to the RAS with the college population. Behavior Therapy, 9, 675 .

Rakos, R.F. 1991. Asser tive Behavior. Theory, Research and Training London: Routledge. 
Reputrawati, A. 1996. Hubungan Antara Asertivitas Dengan Kreativitas Pada Remaja SMA Suku Jawa. Skripsi (Tidak Diterbitkan). Yogyakarta: Fakultas Psikologi Universitas Gadjah Mada.

Retnaningsih, D.(1992). Hubungan antara konsep diri dengan perilaku asertif pada mahasiswa fakultas hukum tahun pertama dan kedua Universitas Gajahmada. Fakultas Psikologi. Universitas Gajahmada.

Rosita, Herni,. (2000) Hubungan Perilaku Asertif dengan kepercayaan Diri Pada Mahasiswa. Jurnal Ilmiah: Universitas Gunadharma.

Sugiyono, 2010, Statistik Untuk Penelitian, Bandung : Alfabeta.

Susanto , A.S. 1985. Pengantar Sosiologi \& Perubahan Sosial . Jakarta : Bina Cipta

Stake, J.E., De Vill, C.J.,\& Pennel, C.L., (1983). The Effects of Assertive Training on the Performance Self Esteem of Adolessent Girl . Journal of Youth and Adolescence. 12, 435-493

Weaver, R. L. (1993). Understanding interpersonal communication . New York: Harpercollins college publisher.

Yogaryjantono. 1991. Asertivitas Antara Perawat Ruang VIP dan Perawat Ruang Bangsal di Rumah Sakit Panti Rapih Yogyakarta. (Skripsi tidak diterbitkan) 